University of Nebraska - Lincoln

DigitalCommons@University of Nebraska - Lincoln

\title{
Isolation and characterization of porcine visceral endoderm cell lines derived from in vivo 11-day blastocysts
}

Neil C. Talbot

USDA-ARS, Ntalbot@anri.barc.usda.gov

Le Ann Blomberg

USDA-ARS, leann.blomberg@ars.usda.gov

Ayesha Mahmood

USDA-ARS

Thomas J. Caperna

USDA-ARS

Wesley M. Garrett

USDA-ARS, wesley.garrett@ars.usda.gov

Follow this and additional works at: https://digitalcommons.unl.edu/usdaarsfacpub

Part of the Agricultural Science Commons

Talbot, Neil C.; Blomberg, Le Ann; Mahmood, Ayesha; Caperna, Thomas J.; and Garrett, Wesley M., "Isolation and characterization of porcine visceral endoderm cell lines derived from in vivo 11-day blastocysts" (2007). Publications from USDA-ARS / UNL Faculty. 691.

https://digitalcommons.unl.edu/usdaarsfacpub/691

This Article is brought to you for free and open access by the U.S. Department of Agriculture: Agricultural Research Service, Lincoln, Nebraska at DigitalCommons@University of Nebraska - Lincoln. It has been accepted for inclusion in Publications from USDA-ARS / UNL Faculty by an authorized administrator of DigitalCommons@University of Nebraska - Lincoln. 


\title{
Isolation and characterization of porcine visceral endoderm cell lines derived from in vivo 11-day blastocysts
}

\author{
Neil C. Talbot • Le Ann Blomberg • Ayesha Mahmood • \\ Thomas J. Caperna • Wesley M. Garrett
}

Received: 29 December 2006 / Accepted: 2 February 2007 / Published online: 16 March 2007 / Editor: J. Denry Sato (C) The Society for In Vitro Biology 2007

\begin{abstract}
Two porcine cell lines of yolk-sac visceral endoderm, designated as PE-1 and PE-2, were derived from in vivo 11-d porcine blastocysts that were either ovoid (PE-1) or at the early tubular stage of elongation (PE-2). Primary and secondary culture of the cell lines was done on STO feeder cells. The PE-1 and PE-2 cells morphologically resembled visceral endoderm previously cultured from in vivo-derived ovine and equine blastocysts and from in vitro-derived bovine blastocysts. Analysis of the PE-1- and PE-2-conditioned medium by 2D-gel electrophoresis and matrix-assisted laser desorption/ionization-time-of-flightmass spectrometry demonstrated that they produced serum proteins. Reverse transcriptase polymerase chain reaction analysis showed that the cells expressed several genes typical for yolk-sac endoderm differentiation and function including GATA-6, DAB-2, REX-1, HNF-1, transthyretin, alpha-fetoprotein, and albumin. Unlike a porcine liver cell line, the PE-1 and PE-2 cell lines had relatively low inducible P-450 content and EROD activity, and, while they cleared ammonia from the cell culture medium, they did not produce urea. Transmission electron microscopy revealed that the cells were a polarized epithelium connected by complex junctions resembling tight junctions and by lateral desmosomes. Rough endoplasmic reticulum was prominent within the cells. Immunocytochemistry
\end{abstract}

N. C. Talbot $(\varangle) \cdot$ L. A. Blomberg · W. M. Garrett

Biotechnology and Germplasm Laboratory,

Animal and Natural Resources Institute, ARS, USDA,

Bldg. 200, Rm. 13, BARC-East,

Beltsville, MD 20705, USA

e-mail: Ntalbot@anri.barc.usda.gov

A. Mahmood · T. J. Caperna

Growth Biology Laboratory,

Beltsville Agricultural Research Center,

Beltsville, MD 20705, USA indicated that the PE-1 cells expressed cytokeratin 18 and had robust microtubule networks similar to those observed in in vivo porcine yolk-sac endoderm. Metaphase spreads prepared at passage 26 of the PE-1 cell line indicated a diploid porcine karyotype of 38 chromosomes. The cells have been grown for over $1 \mathrm{yr}$ for multiple passages at 1:10 or 1:20 split ratios on STO feeder cells. The cell lines will be of interest as an in vitro model of the porcine preimplantation yolk-sac tissue.

Keywords Cell $\cdot$ Line $\cdot$ Endoderm $\cdot$ Pig $\cdot$ Porcine $\cdot$ Yolk-sac

\section{Introduction}

Visceral or yolk-sac endoderm cells derive from the primitive endoderm or hypoblast (Kadokawa et al., 1987) and form the yolk sac which is ventral to the early porcine embryo (embryonic disc) and is adjacent to, and continuous with, the inner aspect of the trophectoderm as it rapidly expands to form the filamentous blastocyst stage by 2 wk postfertilization (Marrable, 1971; Anderson, 1978; Carlson, 1981; Stroband et al., 1984; Liwska and Grabinski-Baranowski, 1994). As gastrulation proceeds, mesoderm cells delaminate from the embryonic disc and rapidly cover the visceral endoderm epithelial sheet (splanchnic mesoderm) so as to contribute to a vascular network that develops within the yolk-sac tissue (Marrable, 1971; Tiedemann and Minuth, 1980; Carlson, 1981; Liwska and Grabinski-Baranowski, 1994). The yolk sac persists for several wk until the chorioallantoic membranes are established. After this time, it rapidly shrinks in size, and the remnant is finally absorbed into the belly stalk of the fetus (Marrable, 1971; Tiedemann and Minuth, 1980; Carlson, 1981; Mossman, 1987; Liwska and Grabinski-Baranowski, 1994). 
Although the yolk sac of mammals is referred to as a vestigial structure because no yolk is actually present for the tissue layer to surround, it carries out various important functions in the developing embryo during the preimplantation and periimplantation periods of pig development (Minuth and Tiedemann, 1980; Tiedemann and Minuth, 1980; Carlson, 1981; Mossman, 1987; Liwska and GrabinskiBaranowski, 1994). The yolk-sac epithelial layer being in direct contact with an extensive area of the chorion (trophectoderm), and this in close apposition to the uterine endometrium, is positioned to facilitate nutrient transport from the uterus to the embryo and early fetus (Marrable, 1971; Carlson, 1981; Mossman, 1987). The yolk sac also supports the early development of the fetus by producing a spectrum of serum proteins (Minuth and Tiedemann, 1980; Janzen et al., 1982; Young and Klein, 1983; Shi et al., 1985 ) and functions as the site of early blood cell formation (Marrable, 1971; Tiedemann and Minuth, 1980; Liwska and Grabinski-Baranowski, 1994; Niimi et al., 2002). These functions are of particular importance in the pig because formation of the placenta is delayed and does not begin until after approximately $18 \mathrm{~d}$ of gestation (Marrable, 1971; Anderson, 1978; Carlson, 1981). The yolk sac, therefore, has the specialized function of supporting the early development of the fetus until nutrient and physiological support is taken over by the formation of the chorioallantois and its connection with the uterus, i.e., placentation (Tiedemann and Minuth, 1980; Carlson, 1981; Stroband et al., 1984; Liwska and Grabinski-Baranowski, 1994; Bavik et al., 1996).

In vitro models of porcine yolk-sac endoderm, i.e., extraembryonic visceral endoderm, are not available for the study of periimplantation porcine embryo development. In vitro models of visceral endoderm exist for the mouse (Walter et al., 1984; Adamson et al., 1985; Mummery et al., 1991) and the human (Pera et al., 1987). However, the greatly delayed implantation of ungulate embryos together with the extensive size of the porcine yolk sac suggests that the proper formation and function of the yolk sac may be particularly vital to the survival of porcine embryos (Marrable, 1971; Carlson, 1981). Thus, porcine visceral endoderm cell lines may offer a more relevant in vitro cellular substrate with which we can study yolk-sac function and mechanisms of periimplantation embryo survival in the pig. Given this, models of porcine yolk-sac endoderm may also help illuminate the differences between embryos created by somatic cell nuclear transfer (NT) and embryos derived from normal fertilization via the union of eggs and sperm. Yolk-sac function may be particularly relevant because embryo survival around the time of implantation appears to be a critical point in NT pregnancy failure (Hill et al., 2000; De Sousa et al., 2001; Hashizume et al., 2002). Much of the developmental failure in NT embryos is thought to arise from improper gene imprinting in the first few $d$ of development and the subsequent aberrant gene expression that occurs in hundreds of genes over development, imprinted genes or not (Humpherys et al., 2002; Inoue et al., 2002). Thus, in vitro models of specific early embryonic tissues may facilitate the study of abnormal gene expression in early development. This may be particularly true where transcriptomic or proteomic comparison can be made within well-defined experimental parameters such as in comparing NT embryo-derived tissues to normal embryo-derived tissues. Also, because animal cloning and ungulate embryo acquisition require specialized techniques and expensive animal facilities, in vitro models enable laboratories without such knowledge and facilities to contribute to experimental studies of early ungulate developmental biology.

Recently, in vitro cell culture models of bovine endoderm were reported (Talbot et al., 2000a, 2005). Morphological features of bovine endoderm cells continuously cultured in vitro were similar to those found in vivo, and the cells also displayed in vivo functional characteristics such as serum-protein secretion (Talbot et al., 2000a). The isolation of endoderm cell lines from 11-d porcine blastocysts at the spheroid stage or at the point where elongation had just begun was undertaken. The continuous culture and characterization of the cell lines demonstrated their similarity to each other and establishes their usefulness as in vitro models of the yolk-sac endoderm of pre- and periimplantation pig embryos.

\section{Materials and Methods}

Cell culture. All cells were grown on tissue culture plasticware (Nunc, Denmark; and Falcon, Becton/Dickinson, Lincoln Park, NJ). Cryovials $(2 \mathrm{ml})$ were purchased from Nunc. Fetal bovine serum (FBS) was obtained from Hyclone, Logan, UT. Cell culture media and reagents, including Dulbecco's phosphate-buffered saline (PBS) without $\mathrm{Ca}^{++}$and $\mathrm{Mg}^{++}$, media, trypsin-EDTA $(0.05 \%$ trypsin and $0.43 \mathrm{mM}$ EDTA), penicillin/streptomycin $(5,000 \mathrm{U} / \mathrm{ml} /$ $5,000 \mu \mathrm{g} / \mathrm{ml} ; 100 \times)$, and L-glutamine $(200 \mathrm{mM} ; 100 \times)$, were purchased from Invitrogen Corporation, Gaithersburg, MD (Gibco). STO cells (CRL 1503, American Type Culture Collection, Rockville, MD) were grown in Dulbecco's modified Eagle's medium (DMEM) with high glucose $(4.5 \mathrm{~g} / \mathrm{l})$ supplemented with $10 \%$ FBS (10\% DMEM). Feeder layers were prepared by exposing a suspension of STO cells to $8 \mathrm{krad}$ of gamma radiation and plating the cells at $6 \times 10^{4}$ cells $/ \mathrm{cm}^{2}$. STO feeder layers were maintained by refeeding with $10 \%$ DMEM every 6-7 d.

Cell-growth assays. The growth of PE-1 and PE-2 cells was assayed at passages 16 and 15 , respectively, by 
counting the increase in the total cells per T25 flask over a 1- to 2-wk period at 2- and 3-d intervals postpassage, respectively. Duplicate T25 flasks were counted at each time interval. Single-cell suspensions of the contents of each flask were produced by washing the cells once with $2 \mathrm{ml}$ of $2 \mathrm{M}$ urea. The cells were incubated at $\sim 35^{\circ} \mathrm{C}$ in the residual urea left behind after aspiration $(\sim 0.2 \mathrm{ml})$ for $5-$ $6 \mathrm{~min}$. One-half milliliter of trypsin-EDTA was added to each T25 flask to complete the dissociation of the cells during an additional $10 \mathrm{~min}$ incubation at $\sim 35^{\circ} \mathrm{C}$. The cells were suspended to a total volume of $2 \mathrm{ml}$ for cell counts in $10 \%$ DMEM. The total number of cells per T25 flask was determined by averaging the counts of 16 hemocytometer squares $\left(1 \mathrm{~mm}^{2}\right)$. The input of the number of PE-1 and PE-2 cells at the start of the growth assay was undefined but was a 1:12 split ratio from confluent stock cultures of each cell line. STO feeder cells surviving the urea/trypsin/EDTA dissociation were similarly enumerated from a parallel group of feeder-cell T25 flasks that had not received any PE-cell input.

The growth of the PE-1 and PE- 2 cell lines (at passages 21 and 20, respectively) was also demonstrated by photo documentation of sister flasks of the culture that were simultaneously fixed and stained at progressively longer time points postpassage. Fixation and staining of the cultures were performed by aspirating the medium from the flasks and immediately replacing it with a fixing/ staining solution of $0.125 \%$ Coomassie Blue R-250 (Invitrogen/Gibco), 50\% methanol, and 10\% acetic acid for $10 \mathrm{~min}$. The staining solution was decanted, and the cell monolayer was rinsed with distilled water to stop cell staining. If necessary, the stained cells were destained to varying degrees with a solution of $50 \%$ methanol and $10 \%$ acetic acid.

Cytogenetic analysis. PE-1 cells were analyzed for chromosome content at passage 26 . PE cells were harvested to single cells by treatment with $2 \mathrm{M}$ urea and trypsin-EDTA as previously described to prepare metaphase spreads (Talbot et al., 2000a). Metaphase spreads on replicate slides were stained with $1 \mu \mathrm{g} / \mathrm{ml}$ propidium iodide (PI; Molecular Probes, Eugene, OR) and $2 \mu \mathrm{g} / \mathrm{ml}$ bisbenzimide (Hoechst 33342; Molecular Probes) for fluorescent observation. For chromosome counts, PI-stained metaphase spreads were imaged at $\sim 1,000 \times$ magnification using a Zeiss LSM 410 Confocal Microscope equipped with a $63 \times$ C-Apochromat 1.2 NA water immersion objective. For Hoechst 33342 fluorescent observation, the 351-nm line of a Coherent Innova 90 laser was used for excitation, and the emitted light was passed through a long-pass 397-nm filter. The 568-nm line of an argon/krypton laser was used for excitation of PI, and the emitted light was filtered through a long-pass 590-nm emission filter. Thirty-three PE-1 metaphase spreads were counted for chromosome content.
Immunocytochemistry. PE-1 cells at passage 26 were fixed for $25 \mathrm{~min}$ in $4 \%$ methanol-free formaldehyde in PBS. The bottoms of the flasks were cut out and processed for immunocytochemistry as previously described (Talbot et al., 2003). A mixture of antibodies to alpha-tubulin (1:1,000; Sigma Chemical Co., St. Louis, MO) and betatubulin antibody (1:500; Sigma) was employed for the detection of tubulin, and the anti-cytokeratin-18 antibody (monoclonal M30; 1:1,000; Roche Applied Science, Indianapolis, $\mathrm{IN}$ ) was used for the detection of cytokeratin 18 . Alexa 488-labeled goat anti-mouse secondary antibody (Molecular Probes, Eugene, OR) was used to detect binding of the primary antibodies. The actin cytoskeleton was stained with Alexa Fluor 594 phalloidin (Molecular Probes) at $2 \mathrm{U} / \mathrm{ml}(66 \mathrm{nM})$. Cell nuclei were counterstained with $500 \mathrm{ng} / \mathrm{ml}$ bisbenzimide (Hoechst 33342; Molecular Probes), and the specimens were mounted in Vectashield (Vector Labs, Burlingame, CA).

Two-dimensional electrophoretic analysis of conditioned medium. A T25 culture of PE-1 cells at passage 2 was rinsed three times with serum-free DMEM and then cultured for $48 \mathrm{~h}$ in serum-free medium. The conditioned medium (CM) was collected, and the cell debris was pelleted by centrifugation at $\sim 500 \times g$ for $15 \mathrm{~min}$. The first dimension isoelectric focusing (IEF) was performed using a 7-cm immobilized $\mathrm{pH}$ gradient strip (IPG; pH 3-10; GE Healthcare, Piscataway, NJ) in the IPGphor II system (GE Healthcare). The CM was concentrated $\sim 18$-fold and fluid exchanged with water $1 \times$ using a $500-\mu \mathrm{l}, 3 \mathrm{kDa}$ cutoff, Vivaspin concentrator (Vivaspin, Hanover, Germany). The concentrated sample (12 $\mu \mathrm{l} ; \sim 150 \mu \mathrm{g}$ protein) was brought to $130 \mu \mathrm{l}$ total volume with rehydration buffer [ $8 \mathrm{M}$ urea (Bio-Rad, Hercules, CA), 2\% CHAPS (Sigma), $27 \mathrm{mM}$ dithiothreitol (DTT; USB Corp., Cleveland, $\mathrm{OH}$ ), $0.5 \%$ ampholytes (GE Healthcare), and $0.001 \%$ bromophenol blue (Sigma)], and $120 \mu$ of the sample was applied to the IPG strip. The strip was passively rehydrated for $\sim 14 \mathrm{~h}$ at room temperature, and voltage settings for IEF were $500 \mathrm{~V}$ for $30 \mathrm{~min}, 1,000 \mathrm{~V}$ for $30 \mathrm{~min}$, and $8,000 \mathrm{~V}$ for $1 \mathrm{~h}$. The total volt hours reached in the run was $4,402 \mathrm{Vh}$. The gel strip was incubated with an equilibration buffer $[0.4 \mathrm{M}$ Tris- $\mathrm{HCl}$ at $\mathrm{pH} 8.8,6 \mathrm{M}$ urea, $30 \%$ glycerol, $2 \%$ sodium dodecyl sulfate (SDS; USB Corp.), $1 \%$ DTT, and $0.001 \%$ bromophenol blue] for $15 \mathrm{~min}$. The strip was placed onto a $10 \%$ SDS-polyacrylamide gel $(8 \times 10 \mathrm{~cm})$ with Tris-glycine buffer system, as described by Laemmli (1970), for the second dimension protein separation. The strip was overlaid with $2.5 \%$ lowmelting agarose sealing solution [0.5\% agarose and $0.001 \%$ bromophenol blue in SDS electrophoresis buffer $(25 \mathrm{mM}$ Tris base, $192 \mathrm{mM}$ glycine, and 0.1\% SDS)]. Electrophoresis was performed using the Mini PROTEAN II system (Bio$\mathrm{Rad})$ at room temperature. The proteins in the gel were visualized by staining with Colloidal Coomassie Blue G-250 
(Gradipure $^{\circledR}$; Life Therapeutics, Frenchs Forest, Australia) and destaining the gel according to the manufacturer's instructions. The gel was scanned using laser densitometry (PDSI, GE Healthcare) and was stored in 10\% ammonium sulfate solution at room temperature.

Mass spectrophotometric analysis of proteins. Protein spots were excised from 2D gels using standard pipette tips, and the gel "plugs" were washed first with a destaining solution [water to methanol to acetic acid (4.5:4.5:1)], then in $\mathrm{dH}_{2} \mathrm{O}$, and finally in $50 \%$ acetonitrile containing $25 \mathrm{mM}$ ammonium bicarbonate. Each gel plug was dehydrated with $100 \%$ acetonitrile, dried under vacuum, and then rehydrated in trypsin (modified porcine trypsin, sequencing grade, Promega, Madison, WI) in $25 \mathrm{mM}$ ammonium bicarbonate. An additional aliquot of $25 \mathrm{mM}$ ammonium bicarbonate was added to cover the gel plug. Digestion was performed overnight at $37^{\circ} \mathrm{C}$. The resulting tryptic fragments were extracted with $50 \%$ acetonitrile and $5 \%$ trifluoroacetic acid (TFA) with sonication. The extracted peptide fragments were dried to completeness by vacuum centrifugation and then dissolved in $50 \%$ acetonitrile and $0.1 \%$ TFA and analyzed immediately or stored at $-80^{\circ} \mathrm{C}$. Samples were cocrystallized with freshly prepared $\alpha$-cyanohydroxycinnamic acid matrix (Bruker Daltonics, Billerica, MA) in $50 \%$ acetonitrile and $0.1 \%$ TFA. Samples were spotted directly on the target plate. The dried spots were further desalted with a brief application of $0.1 \%$ TFA $(3 \mu \mathrm{l})$, followed by immediate vacuum aspiration, and were subjected to matrix-assisted laser desorption/ionizationtime of flight-mass spectrometry (MALDI-TOF-MS) analysis. A Voyager DE-STR MALDI-TOF mass spectrometer (Applied Biosystems, Framingham, MA) operated in positive ion reflector mode was used to analyze tryptic peptides, and spectra were acquired with 75 shots of a $337-\mathrm{nm}$ nitrogen laser operating at $20 \mathrm{~Hz}$. Spectra were calibrated using the trypsin autolysis peaks at $m / z 842.51$ and $2,211.10$ as internal standards.

A Thermo Finnigan LCQ Deca XP plus Ion Trap mass spectrometer was used to analyze proteins that were not positively identified by MALDI-TOF-MS. Peptides were separated on a reverse phase column using a 30-min gradient of 5 to $60 \%$ acetonitrile-to-water, $0.1 \%$ formic acid. After a survey scan from 400 to $1,600 \mathrm{Da}$, the MS/MS spectra were acquired on the three most abundant ions. Dynamic exclusion was employed to prevent the continuous analysis of the same ions. The raw data were processed by Sequest to generate DTA files for database searching. The merge.pl script from Matrix Science was used to convert multiple Sequest DTA files into a single Mascot generic file suitable for searching in Mascot.

Protein identification was performed by searching the NCBI nonredundant database using the Mascot search engine (http://www.matrixscience.com). The following parameters were used for database searches with MALDTOF peptide mass fingerprinting data: monoisotopic mass, $25 \mathrm{ppm}$ mass accuracy, trypsin as digesting enzyme with one missed cleavage allowed, oxidation of methionine, and $\mathrm{N}$-terminal pyroglutamic acid from glutamic acid or glutamine as allowable variable modifications. For database searches with MS/MS spectra, the following parameters were used: monoisotopic mass, $1 \mathrm{Da}$ peptide and MS/MS mass tolerance, peptide charge of $+1,+2$, or +3 , trypsin as digesting enzyme with one missed cleavage allowed, oxidation of methionine, and $\mathrm{N}$-terminal pyroglutamic acid from glutamic acid or glutamine as allowable variable modifications. Taxonomy was limited to mammals for both MALDI and MS/MS ion searches. For MALDI-TOF-MS data to qualify as a positive identification, a protein's score had to equal or exceed the minimum significant score. Positive identification of proteins by MS/MS analysis required a minimum of two unique peptides, with at least one peptide having a significant ion score.

Metabolic assays: $P-450, \gamma$-glutamyltranspeptidase, ammonia, and urea. P-450 content and $\gamma$-glutamyltranspeptidase (GGT) assays: T25 cultures of PE-1 and PE-2 cells were grown to confluence at passage levels 16 and 15 , respectively, and were harvested for whole-cell homogenates and microsomes. Two days before the harvest, the cultures were exposed to metyrapone to stimulate and preserve $\mathrm{P}-450$ expression. P-450 content and GGT activity were determined as previously described (Talbot et al., 1996) from a pool of three flasks for each cell line. A porcine liver stem cell line, PICM-19 (Talbot et al., 1994, 1996), was also assayed as a comparative positive control.

Ammonia clearance and urea production: As above, the confluent cultures of PE-1, PE-2, and PICM-19 cells were exposed to glutamine-free Williams-E medium supplemented with $10 \% \mathrm{FBS}, 1 \mathrm{mM}$ ornithine, glucagon $(100 \mathrm{ng} / \mathrm{ml}), 2$ mercaptoethanol $(0.1 \mathrm{mM})$, HEPES ( $25 \mathrm{mM})$, and antibiotics for $72 \mathrm{~h}$. The cells were then exposed to the same base medium with the addition of $2 \mathrm{mM}$ ammonium chloride for $48 \mathrm{~h}$. The medium was collected, centrifuged at 2,000 $\mathrm{g}$ to remove cellular debris, and frozen at $-80^{\circ} \mathrm{C}$ before analysis. The ammonia content of experimental $(48 \mathrm{~h})$ and initial $\left(T_{0}\right)$ media samples was determined spectrophotometrically using a commercial kit (Pointe Scientific, Inc., Canton, MI) which was modified for use in a microtiter plate reader. A standard curve was prepared in base medium without ammonia.

Urea concentration in medium was determined colorimetrically based on a diacetyl monoxime reaction assay described by the World Health Organization (Wybenga et al., 1971; Seaton and Ali, 1984). Absorbance was determined at $540 \mathrm{~nm}$, and a standard curve was prepared (NERL 2336; NERL Diagnostics, East Providence, RI). Values from base medium were subtracted from experimental samples. 
P-450 CYPA1 activity: As above, confluent cultures of PE-1, PE-2, and PICM-19 cells were preincubated with $5 \mu \mathrm{M}$ 3-methyl cholanthrene (3MC) in culture medium for $72 \mathrm{~h}$ to induce CYPA1 activity. Cells were then exposed to Medium 199 medium with Hank's salts without L-glutamine or sodium bicarbonate and containing 7-ethoxyresorufin $(8 \mu \mathrm{M})$, dicumerol $(10 \mu \mathrm{M})$, and bovine serum albumin for $30 \mathrm{~min}$ as described by Donato and coworkers (1993). The medium was harvested, and the concentration of the fluorescent product, resorufin, was assayed in the presence and absence of $\beta$-glucuronidase/arylsulfatase (Roche Applied Sciences, Mannheim, Germany) to determine the extent of possible conjugation reactions. All reagents were from Sigma-Aldrich (St. Louis, MO), and the activity was presented as picomole product formed per $30 \mathrm{~min} / \mathrm{mg}$ cell protein in cultures prepared with and without $3 \mathrm{MC}$.

$R N A$ isolation and RT-PCR assay. Total RNA was isolated from four confluent T25 cultures of PE-1 and PE2 cells at passages 16 and 15 , respectively, with the RNAeasy Kit (Qiagen, Valencia, CA) according to the manufacturer's instructions. Ten micrograms of total RNA from each sample was digested for $30 \mathrm{~min}$ with DNase I (Turbo DNA Kit, Ambion, Austin, TX). Gene-specific primers (Table 1) for select endoderm differentiation regulators or tissue-specific transcripts and $\beta$-actin were synthesized according to porcine-specific sequences obtained from
GenBank (http://www.ncbi.nlm.nih.gov/entrez/query.fcgi) or The Institute for Genome Research (TIGR, Rockville, MD; $\mathrm{http} / / / \mathrm{www}$. tigr.org/tdb/tgi/ssgi) porcine gene index databases. Sequence analysis of the $\beta$-actin primers indicated that they would also amplify mouse $\beta$-actin. One microgram of total RNA was reverse transcribed (RT) in a $20-\mu$ l reaction volume using the iScript cDNA Synthesis Kit (BioRad, Hercules, CA) following the manufacturer's protocol. Amplification of gene products by RT-PCR was performed in a $50-\mu$ l reaction volume containing $1 \mu \mathrm{l}$ RT product, $0.1 \mu \mathrm{M}$ gene-specific forward and reverse primers, $0.1 \mathrm{mM}$ dNTPs, 1× HotMaster PCR buffer (Eppendorf, Westbury, NJ), and 1 U HotMaster Taq polymerase (Eppendorf). The PCR was carried out in the DNA Engine Tetrad 2 (MJR, Waltham, MA) under the following conditions: denaturation at $95^{\circ} \mathrm{C}$ for $2 \mathrm{~min}$ followed by $\left[94^{\circ} \mathrm{C}\right.$ for $15 \mathrm{~s}, 60^{\circ} \mathrm{C}$ for $15 \mathrm{~s}$, and $70^{\circ} \mathrm{C}$ for $\left.15 \mathrm{~s}\right] \times 34$ or 36 cycles. Amplification products were resolved on $2 \%$ agarose gels and visualized with ethidium bromide staining.

Transmission electron microscopy. Transmission electron microscopy (TEM) sample preparation and photomicroscopy were done with the assistance of JFE Enterprises, Brookeville, MD as previously described (Talbot et al., 2000b). Ultrastructural analysis was performed on samples processed from T25 flask cultures of PE-1 and PE-2 that were 3 wk old at passages 15 and 16 , respectively.
Table 1. RT-PCR primer sets

TIGR accession numbers are preceded by TC; all other accession numbers are from GenBank.

$\mathrm{F}=$ Forward primer, $\mathrm{R}=$ reverse primer

\begin{tabular}{|c|c|c|}
\hline Gene & Primer & Database accession no. \\
\hline$\alpha$-Fetoprotein & $\begin{array}{l}\text { F: 5'-AGATGCCCATAAACCCTGGT-3' } \\
\text { R: 5'-CCAGTAGTCCAGAGAAATCTGCA-3' }\end{array}$ & TC219856 \\
\hline$\alpha$-Cardiac actin & $\begin{array}{l}\text { F: 5'-CAGGTATTGCTGATCGCATGCA-3' } \\
\text { R: 5'-ATTTGCGGTGGACGATGGA-3' }\end{array}$ & TC206532 \\
\hline Oct-3/4 & $\begin{array}{l}\text { F: 5'-GCAAACGATCAAGCAGTGA-3' } \\
\text { R: 5'-GGTGACAGACACCGAGGGAA-3' }\end{array}$ & TC205936 \\
\hline Transthyretin & $\begin{array}{l}\text { F: 5'-ATGGTCAAAGTCCTGGATGCT-3' } \\
\text { R: 5'-GATTTGGTGTCCAATTCCACT-3' }\end{array}$ & $X 87846$ \\
\hline Albumin & $\begin{array}{l}\text { F: 5'-TGTTGCTGATGAGTCAGCTGA-3' } \\
\text { R: 5'-TGGAAGTCAGCGCATAAAGCA-3' }\end{array}$ & NM_001005208 \\
\hline GATA-6 & $\begin{array}{l}\text { F: 5'- CAGGAAACGAAAACCTAAGAGCAT-3' } \\
\text { R: 5'-TTCTCGGGATTAGCGCTCTC-3' }\end{array}$ & TC221844 \\
\hline HNF-1 & $\begin{array}{l}\text { F: 5' GTTGCAGAAAAGCGCAGTGA-3' } \\
\text { R: 5'-CGTCGAAGGAGCACAAGGTAG-3' }\end{array}$ & TC222968 \\
\hline DOC-2/Dab-2 & $\begin{array}{l}\text { F: 5'-CACTTTGCCATGCACCCTC-3' } \\
\text { R: 5'-AGGTGTGTCAGATTCCAAAGTCC-3' }\end{array}$ & TC202780 \\
\hline Rex-1 & $\begin{array}{l}\text { F: 5'-TTTCTGAGTACGTGCCAGGCAA-3' } \\
\text { R: 5'-GAACGGAGAGATGCTTTCTCAGAG-3' }\end{array}$ & TC206552 \\
\hline Cytokeratin 8 & $\begin{array}{l}\text { F: 5'-TGGGATGCAGAACATGAGTATCC-3' } \\
\text { R: 5'-TGGTAGGAGCTCAGGCTGTAGTT-3' }\end{array}$ & TC199401 \\
\hline Cytokeratin 18 & $\begin{array}{l}\text { F: 5'-CAACGCCAGACCCAGGAGTA-3' } \\
\text { R: 5'-AAGATTGAAGTCCTCGCCATCTT-3' }\end{array}$ & TC200462 \\
\hline$\beta$-Actin & $\begin{array}{l}\text { F: 5'-TGTCCACCTTCCAGCAGATGT-3' } \\
\text { R: 3'-ATGCAACTAACAGTCCGCCTAGA-3' }\end{array}$ & AY550069 \\
\hline
\end{tabular}




\section{Results}

Culture characteristics of the PE-1 and PE-2 cell lines. Primary outgrowths of porcine visceral endoderm were initiated by explant culture of 11-d pig blastocysts that had reached the ovoid stage or had just begun elongation and were tubular in shape. For primary explant culture, a portion of each blastocyst's trophectoderm/endoderm bilayer was chopped into over a dozen small pieces, and the pieces were transferred to a four-well plate (Nunc) containing an established STO feeder layer and $1 \mathrm{ml}$ of $10 \%$ DMEM. Primary endoderm outgrowths were recognized by their distinct cell and colony morphology (Talbot et al., 2000a). Based on microscopic observation of cell and colony morphology, no epiblast tissue contaminated the primary cultures. This was as expected since the epiblast tissue (embryonic disc) had been avoided in the physical dissection of the blastocyst's trophectoderm/endoderm tissue bilayer. Outgrowths of trophectoderm cell monolayers were found in both primary cultures, and these were removed by dissection with $27 \mathrm{G}$ hypodermic needles. The trophectoderm cell monolayers detached neatly as an intact unit from the adjacent endoderm monolayers and the plastic substrate, and they were removed by aspiration with a Pasteur pipette.

The primary PE colonies were composed of cuboidal epithelial cells closely packed together in the center of the colony with flatter and more spread out cells at the periphery of the colony (as in Fig. $1 A$ ). The primary colonies often had domes created by the apical to basal transcellular movement of culture fluid that became trapped underneath the endoderm monolayer. Also, groups of endoderm cells on the surface of the colony's monolayer often formed vesicle-like structures by transporting fluid between themselves. The cells were not as granular in appearance as trophectoderm cells and had few or no visible lipid droplets associated with them. Additionally, at the periphery of the colonies or where cells had made dome structures, distinct web-like arrangements of phase-contrastdark cytoskeletal fibers were observed in the cells (as in Fig. $1 B$ ). The cells grew predominantly on top of the STO feeder cells as a tightly knit monolayer of epithelial cells.

First passage and secondary culture of the primary colonies of PE-1 and -2 cells were performed after 3 wk when the colonies had covered approximately $90 \%$ of the surface area of the four-well culture plate and were approximately $1 \mathrm{~cm}$ in diameter. This first passage was accomplished by chopping the primary colonies into small pieces using two hypodermic needles and transferring the resulting clumps of cells into a T25 flask containing a STO feeder-cell layer. The cultures, henceforth designated as the PE-1 cell line (from the ovoid blastocyst) and the PE-2 cell line (from the early tubular blastocyst), were passaged by
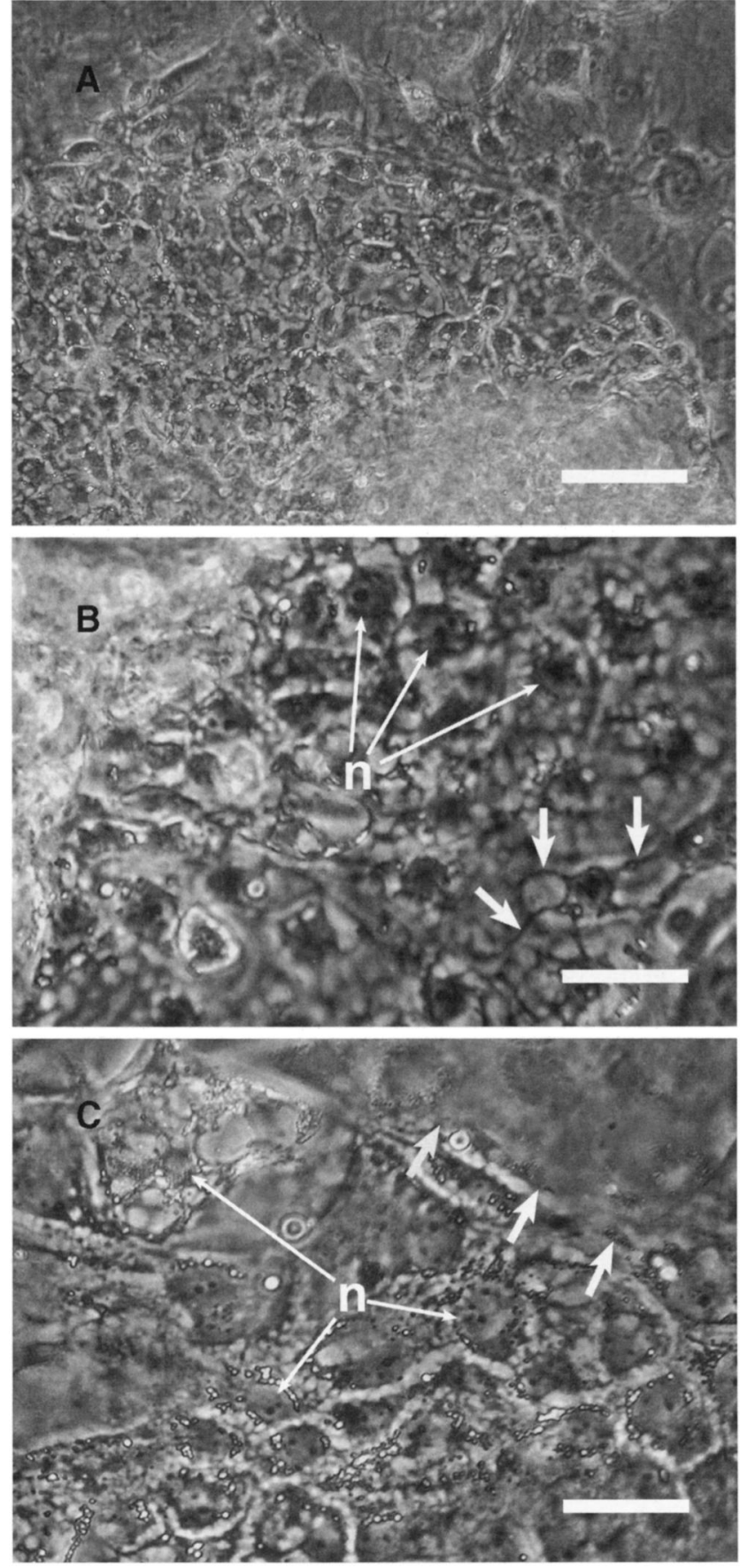

Figure 1. Phase-contrast microscopy of pig endoderm primary cultures and cell lines. $(A)$ Primary colony of yolk-sac endoderm. Scale bar $=50 \mu \mathrm{m}$. $(B)$ Close-up of primary colony cells showing robust microtubule cytoskeletal elements (short arrows) that appear in the cytoplasm and surround the nuclei $(n)$ of the cells. Scale bar= $25 \mu \mathrm{m}$. (C) Monolayer of PE-2 cells at passage 33. Short arrows indicate the edge of a "dome" in the monolayer, and the nuclei $(n)$ are of different sizes depending on the cell-spreading constraints and differentiation status of the cells. The characteristic web-like cytoskeletal elements, so prominent in the primary cells, are also present in some of the later passage cells. Scale bar $=25 \mu \mathrm{m}$. 
physical disruption of the monolayers as previously described in Talbot et al., 2000a. The PE-1 and PE-2 cell lines were passaged approximately every $3 \mathrm{wk}$ at a 1:3 split ratio onto fresh STO feeder layers until approximately passage 10 , and thereafter, they were routinely passaged at a 1:20 split ratio. The cell lines had a characteristic lag period of about 1 wk postpassage that was followed by a population doubling time of approximately $48 \mathrm{~h}$ for PE-1 and somewhat longer for the PE-2 cell line (Figs. 2 and 3).

Similar to the primary culture, the established PE-1 and -2 cell lines formed monolayers composed of cuboidal epithelial cells where most of the cells were closely packed together although in some areas, the cells were flatter and more spread out. Domes and vesicle-like structures were common in the PE monolayers (Fig. $1 B, C$ ). As in the primary culture, some later passaged PE-1 and PE-2 cells were found to have distinctive phase-contrast-dark, weblike cytoskeletal elements that traversed the cytoplasm and encircled the nucleus (as in Fig. 1B). These cytoskeletal elements were positive for reaction with antitubulin antibody by immunocytochemical assay (Fig. 4C) and were therefore microtubules. Similar robust microtubule arrays were also found in the endoderm cells lining the interior of an 11-d in vivo porcine blastocyst (Fig. $4 E$ ). In contrast, the microtubules observed in the in vivo trophectoderm were finer in structure (Fig. 4F). The actin cytoskeleton, while occurring in the cytoplasm of the cells and colocalizing with the microtubule network to some extent, was most distinctly present at the cell boundaries in all cases (Fig. 4D). An anti-cytokeratin-18 antibody also reacted with the PE-1 cells, indicating the protein's presence in the cells (Fig. $4 A$ ), whereas it did not react with the fibroblastic STO feeder cells (not shown).

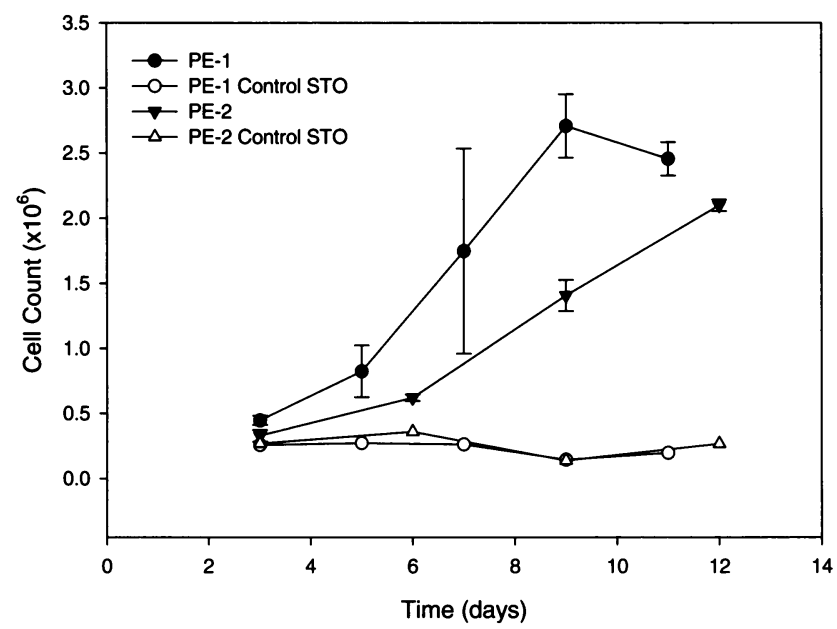

Figure 2. Growth curve of PE-1 and PE-2 cells assayed at passages 16 and 14, respectively. Total of PE-1 and nondividing STO feeder cells (filled circles) and similarly for PE-2 cell line (inverted filled triangles). STO feeder cells only for PE-1 (empty circles) assay and PE-2 assay (unfilled triangles).

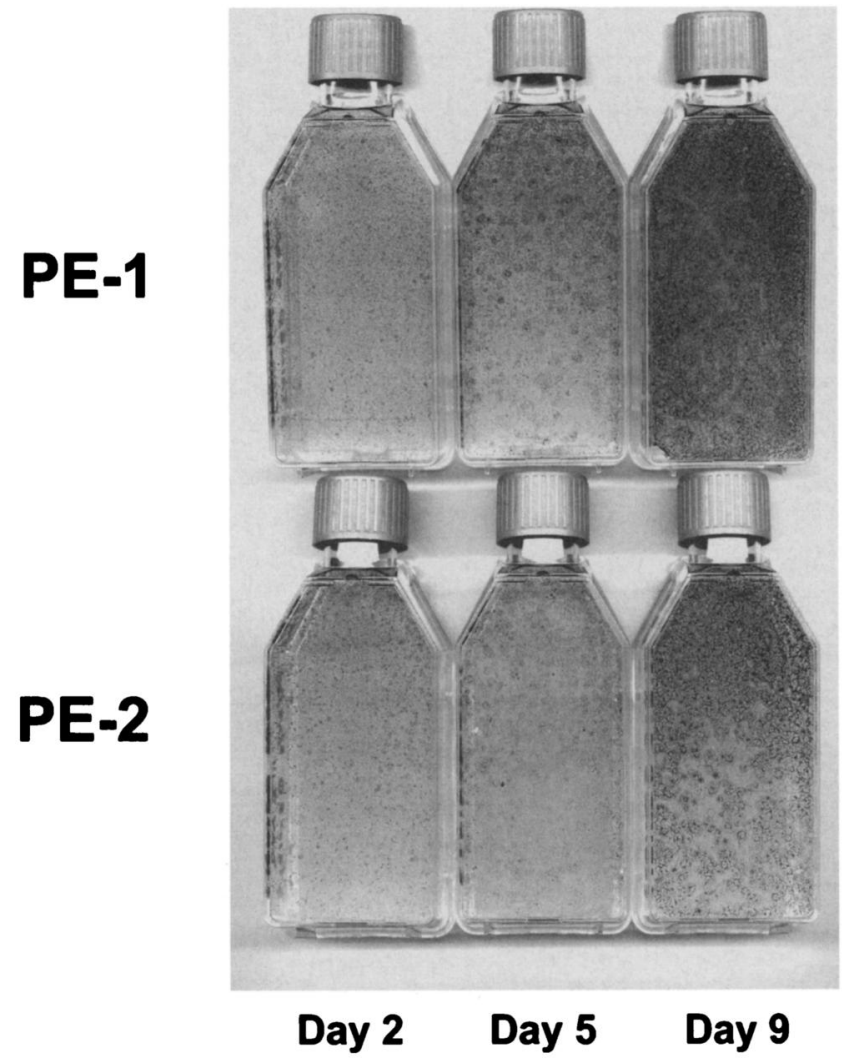

Figure 3. Growth of PE-1 and PE-2 cells shown in a cohort of T25 flasks after passage at a 1:10 split ratio at passage 21 and a 1:5 split ratio at passage 20 , respectively. Individual flasks were fixed and stained over a 9-d period with Coomassie Blue R-250 to illustrate the growth of the cells over time in culture.

TEM analysis of the PE-1 and PE-2 cell lines. PE-1 and PE-2 cells were usually arranged in a single layer of somewhat elongated cuboidal cells (Fig. 5A) although a double-layered dome formation is shown in Fig. $5 B$. While the PE cells were not observed to be intimately joined to the STO feeder cells, they were usually in close proximity to the STO cells except where dome formations occurred (not shown). Microvilli at the apical surface (facing the medium) marked the polarized morphology of the PE cells, and the cells were joined by numerous desmosomal elements and tight junctional complexes at their apical lateral surfaces (Fig. 5A). Smooth and rough endoplasmic reticulum, lysosomes or digestive vacuoles, and lipid vacuoles were all numerous and well represented in the PE cells (Fig. 5A). Golgi complexes, while present (Fig 5A), were not particularly abundant in either the PE-1 or PE-2 cells analyzed by TEM.

Cytogenetic analysis of the PE-1 and PE-2 cell lines. The distribution of chromosome counts was determined from the enumeration of 33 PE-1 metaphase spreads prepared at passage 26. A near unimodal distribution was found in which the majority $(85 \%)$ of PE-1 cells were diploid and contained 38 chromosomes (Fig. 6A). The remaining $15 \%$ of metaphase spreads consisted mostly of 
Figure 4. Confocal immunofluorescent images of anti-cytokeratin-18 and anti-alpha/beta tubulin antibody reactivity in PE-1 (passage 26). Positive anti-cytokeratin-18 staining of PE-1 cells with immunostaining most robust in dividing cells $(A)$ and phalloidin staining of the actin cytoskeleton in the same cells $(B)$. Characteristic web-like array of microtubule (antitubulin) cytoskeletal elements that ramify the cell and surround the nucleus in PE-1 cells $(C)$ and phalloidin staining of the actin cytoskeleton in the same cells $(D)$. Arrows indicate actin staining at the cell borders. For comparative purposes, antialpha/beta tubulin immunostaining of the endoderm cells lining the interior of an $11-d$ in vivo porcine blastocyst $(E)$ and the outer layer of trophectoderm cells $(F)$ is shown. STO feeder cells were below the limit of reactivity for both the anti-cytokeratin- 18 and the antitubulin antibodies (not shown). $n=$ Nucleus; Scale bars $=40 \mu \mathrm{m}$.
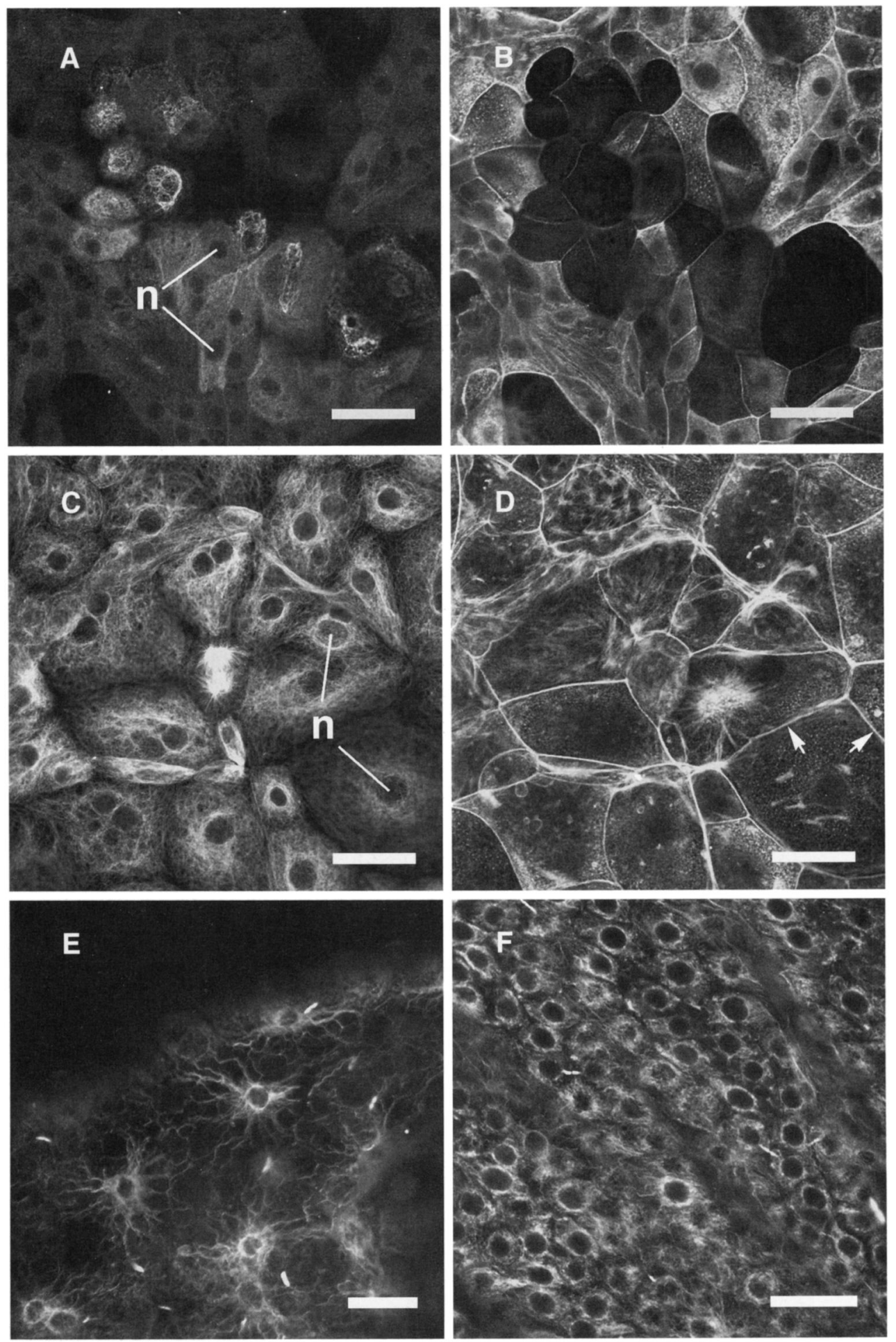

apparently hypodiploid cells, two hyperdiploids, and one near triploid (Fig. 6A). The hypodiploid cells may have resulted from broken metaphase spreads or from the relatively poor quality of the spreads. Two (or more) chromosomes could have been lying across each other and could therefore have easily been counted as one in this circumstance. All the chromosomes were a mixture of metacentrics and telocentrics (Fig. 6B). The metaphase spreads prepared for PE-2 were of insufficient quality to enable accurate counts of 20 spreads presumably because of their relatively slower growth in culture. However, those that appeared to be complete and countable contained 3438 metacentric and telocentric chromosomes (not shown).

Protein expression by PE-1 and PE-2 cells. Visceral endoderm is known to synthesize and secrete serum proteins (Minuth and Tiedemann, 1980; Young and Klein, 

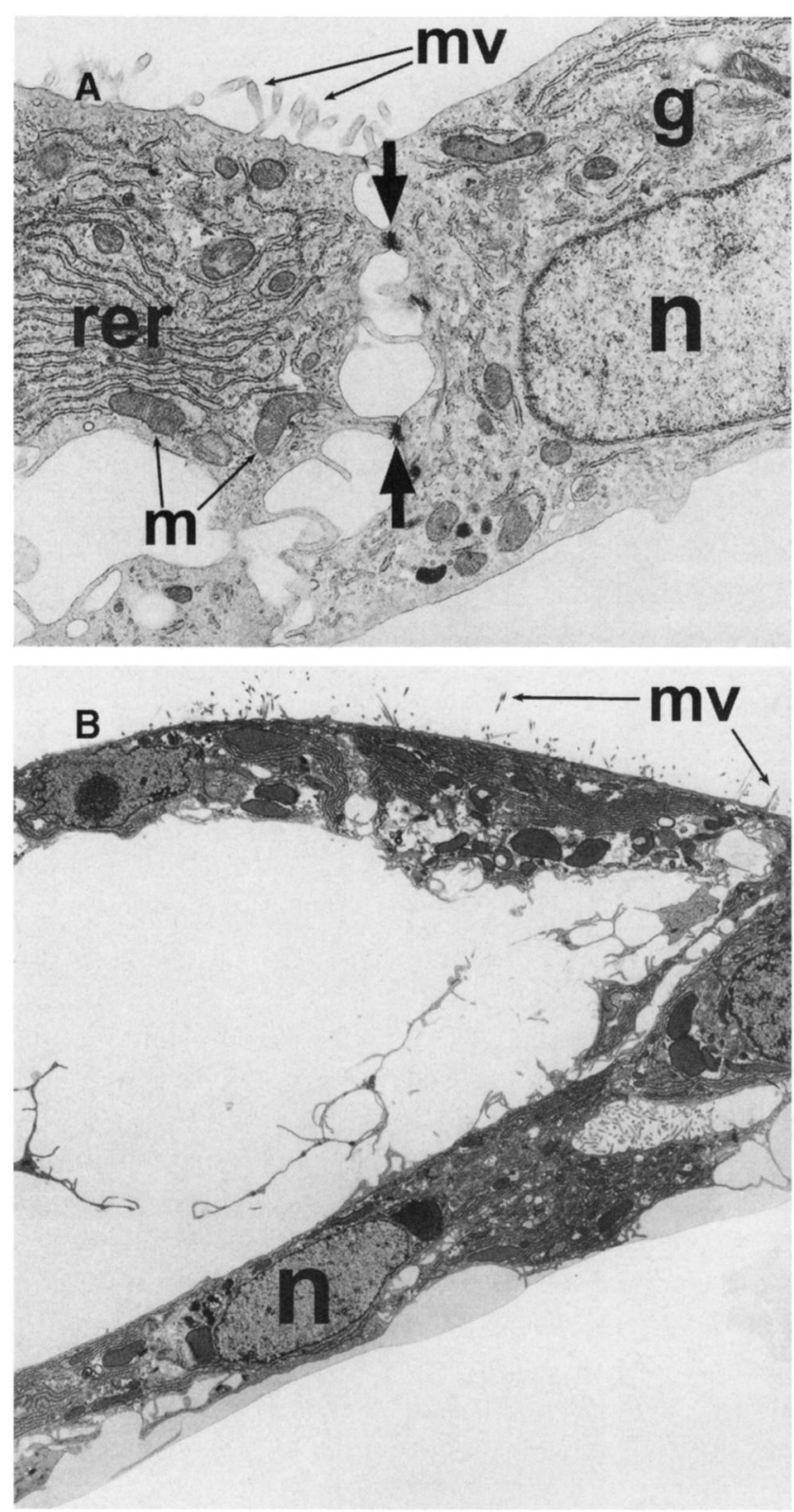

Figure 5. Transmission electron micrographs of PE-1 cells at passage 16. $(A)$ Cell monolayer showing polarized morphology with characteristic apical microvilli $(m v)$ and junctional unions (arrows) along the apical and lateral portions of the approximately cuboidal cells. STO feeder cells are not shown but normally reside underneath the PE-1 cell monolayer. Magnification=24,000×. (B) Functional presence of tight junctions is illustrated in this low-powered image of a fluid-filled "dome" or multicellular cyst-like structure formed by the PE-1 cells. Note the microvilli $(m v)$ at the apical surface of the cells. Magnification $=4,800 \times$. Abbreviations: nucleus $(n)$, rough endoplasmic reticulum (rer), Golgi apparatus $(g)$, mitochondria $(m)$.

1983; Shi et al., 1985; Sklan and Ross, 1987). PE-1 cells were assayed for their secretion of serum proteins. Analysis of serum-free medium conditioned by PE-1 for $48 \mathrm{~h}$ was performed by $2 \mathrm{D}$ polyacrylamide gel electrophoresis and showed that the PE cell line was secreting a spectrum of proteins similar to that found in fetal pig serum (Fig. 7). STO feeder cells alone did not (data not shown; Talbot et al.,
1994, 2000a, 2005). Several of the protein spots were identified by MALDI-TOF and liquid chromatography (LC)-MS/MS mass spectroscopy. The serum proteins identified included alpha-2-HS-glycoprotein precursor (fetuin-A), transthyretin (prealbumin), alpha-fetoprotein (AFP), transferrin, alpha-lipoprotein-A1, and retinol-binding protein (Fig. 7 and Table 2). The Coomassie Blue total protein staining indicated that transferrin, AFP, and fetuin-A were the most abundantly secreted proteins.

Endoderm-related gene expression of $P E-1$ and $P E-2$ cells. The cell lines were assayed by RT-PCR for their expression of mRNA of several genes which are related to visceral endoderm function or differentiation (Table 1). Figure 8 shows that a relatively robust expression was found in both PE-1 and PE-2 cells of transcripts for hepatocyte nuclear factor-4 (HNF4), GATA-6, disabled homolog 2, mitogen-responsive phosphoprotein (DAB2),
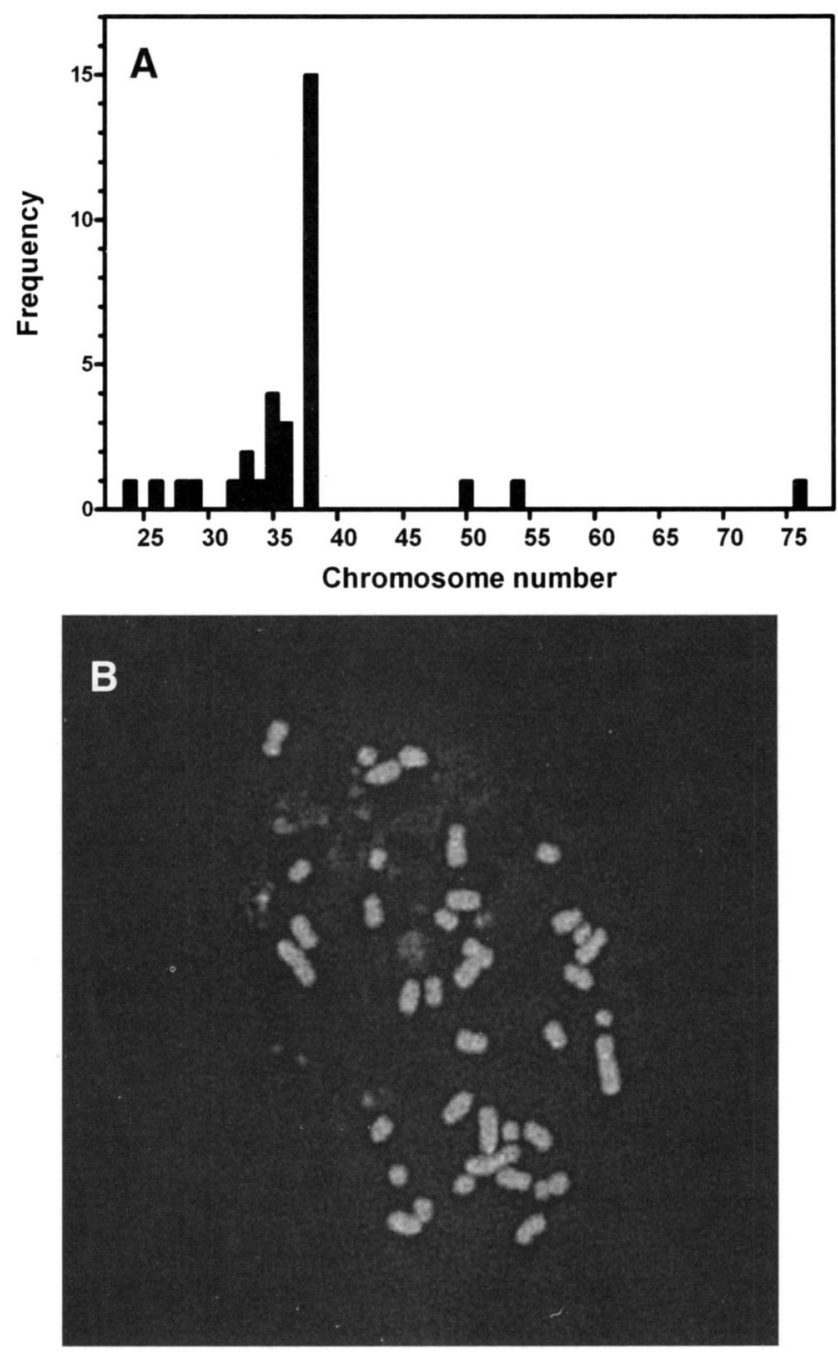

Figure 6. Chromosome content analysis of PE-1 cells at passage 26. Histogram of 33 metaphase spreads of PE-1 cells prepared and counted, which reveals a diploid or near-diploid chromosome distribution $(A)$. An example of a diploid metaphase spread from the PE-1 cell line $(B)$. 


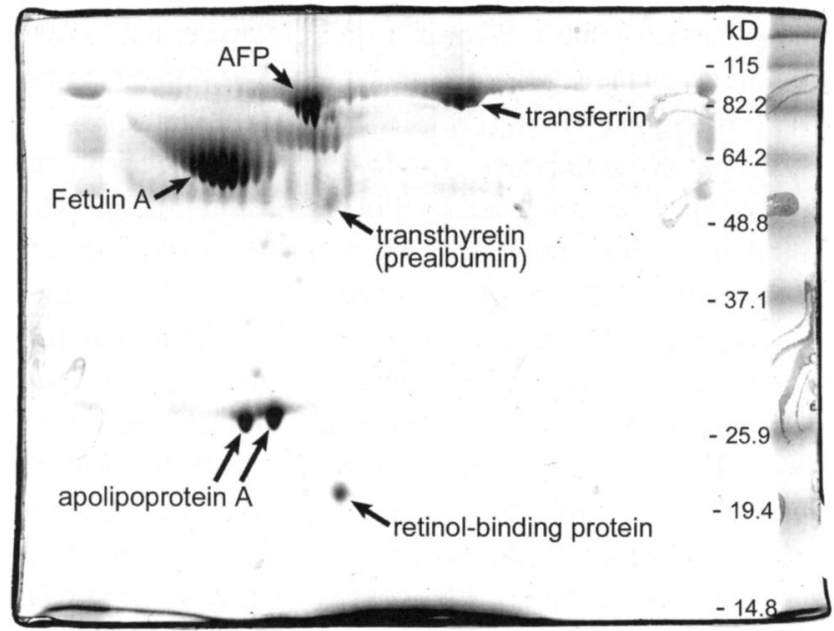

$\mathrm{pH} 3.0$

$\mathrm{pH} 10.0$

Figure 7. Two-dimensional polyacrylamide gel of serum-free medium sample conditioned by a nearly confluent monolayer of PE-1 cell for $48 \mathrm{~h}$; stained with colloidal Coomassie Blue. Some serum proteins, as identified by MALDI-TOF and LC-MS, are indicated (see also Table 2).

reduced expression 1 protein (REX-1), transthyretin (prealbumin; TTR), AFP, and for cytokeratin 8 and 18 (KRT8 and KRT18). Detectable expression levels were also found in the cells for albumin (ALB) and hepatic nuclear factor-1 (TCF-1). With the exception of albumin, the amount of RTPCR reaction products was similar between PE-1 and PE-2 (Fig. 8). Finally, all the cells, including the STO feeder cells alone, were expressing beta-actin (Fig. 8).

Metabolic assays of PE-1 and PE-2 cells. Because yolksac endoderm cells are known to be similar to liver cells (hepatocytes) in some of their metabolic and cell transport functions, the PE- 1 and PE-2 cell lines were analyzed for P-450 content and activity, GGT activity, and their ability to clear ammonia and produce urea (Shi et al., 1985;
Sepulveda et al., 1995). As a positive control, these assays were also performed on the cells of the PICM-19 pig liver cell line (Talbot et al., 1996). Overall cytochrome P-450 levels in the PE cell lines were relatively low compared to the PICM-19 cell line (Fig. 9A). Specific P-450 activity after $3 \mathrm{MC}$ induction as measured by EROD assay was also comparatively low (Fig. 9B). Both PE-1 and PE-2, like the PICM-19 liver cells, were able to completely clear the ammonia added to the cell culture medium (Fig. 9C). In contrast, neither of the PE cell lines produced urea as did the PICM-19 liver cells (Fig. 9C). The PE-2 cells had similar levels of GGT to that of the PICM-19 cells, whereas the PE-1 GGT levels were approximately 50\% lower compared to PE-2 and PICM-19 (Table 3).

\section{Discussion}

This study demonstrates that porcine yolk-sac, visceral endoderm cell lines could be readily established. Because the PE-1 and PE-2 cells have been continuously cultured for nearly $3 \mathrm{yr}$ and for greater than 30 passages, usually at high split ratios, it is probable that the cultures are functionally immortal.

It was not unusual to find trophoblast contamination in the primary blastocyst explant cultures that gave rise to PE cell lines because porcine trophectoderm readily grows on STO feeder cells as previously reported (Flechon et al., 1995; unpublished observations). Trophectoderm outgrowths, recognized by their distinct cell and colony morphology, are easily separated from adjacent endoderm cell monolayers (and the plastic substrate) because the trophectoderm cells form a continuous sheet of cells that are strongly connected to one another and the endoderm monolayer is not strongly adhered to the trophectoderm

Table 2. Proteins identified in the conditioned medium of PE-1 cells by MALDI-TOF and LC-MS/MS

\begin{tabular}{|c|c|c|c|c|c|c|c|c|c|}
\hline $\begin{array}{l}\text { Spot } \\
\text { no. }\end{array}$ & MW & PI & Protein ID & Peptides & $\begin{array}{l}\mathrm{SC} \\
(\%)\end{array}$ & MO & $\begin{array}{l}\text { Expected } \\
\text { value }\end{array}$ & $\mathrm{NCBI}$ & ID method \\
\hline 1 & 76,918 & 6.93 & Chain $\mathrm{A}$, porcine serum transferrin & 17 & 23 & 119 & $6.10 \mathrm{E}-07$ & gi|18655907 & MALDI-TOF \\
\hline 2 & 47,164 & 5.54 & Alpha-1-antitrypsin [Sus scrofa] & 7 & 20 & 84 & 0.0018 & gi|975230 & MALDI-TOF \\
\hline 3 & 68,580 & 5.47 & $\alpha$-Fetoprotein [Sus scrofa] & 10 & 14 & 100 & $4.90 \mathrm{E}-05$ & gi|47523700 & MALDI-TOF \\
\hline 4 & 38,424 & 5.5 & $\begin{array}{l}\text { Alpha-2-HS-glycoprotein precursor } \\
\text { (fetuin-A) }\end{array}$ & 4 & 12 & 268 & & gi $\mid 231467$ & $\mathrm{MS} / \mathrm{MS}$ \\
\hline 5 & 15,792 & 6.34 & $\begin{array}{l}\text { Putative transthyretin (prealbumin) } \\
\text { [Sus scrofa] }\end{array}$ & 6 & 58 & 380 & & gi $\mid 975233$ & MS/MS \\
\hline 6 & 30,312 & 5.38 & Apolipoprotein A-I & 15 & 46 & 193 & $2.40 \mathrm{E}-14$ & gi|164359 & MALDI-TOF \\
\hline 7 & 30,312 & 5.38 & Apolipoprotein A-I & 16 & 54 & 220 & $4.90 \mathrm{E}-17$ & gi|164359 & MALDI-TOF \\
\hline 8 & 21,142 & 5.6 & Retinol-binding protein from pig plasma & 2 & 11 & 88 & & gi|2914422 & MS/MS \\
\hline
\end{tabular}

The assigned protein of the best matched was given with the species in which it has been identified and its accession number.

MW: Predicted molecular weight, PI: predicted isoelectric point, Peptides: the number of peptides matched, SC: the percentage of sequence coverage, MO: MOWSE score, Expected value: the number of matches with equal or better scores that are expected to occur by chance alone (http://www.matrixscience.com), NCBI: accession number, ID method: mass spectroscopy identification method 


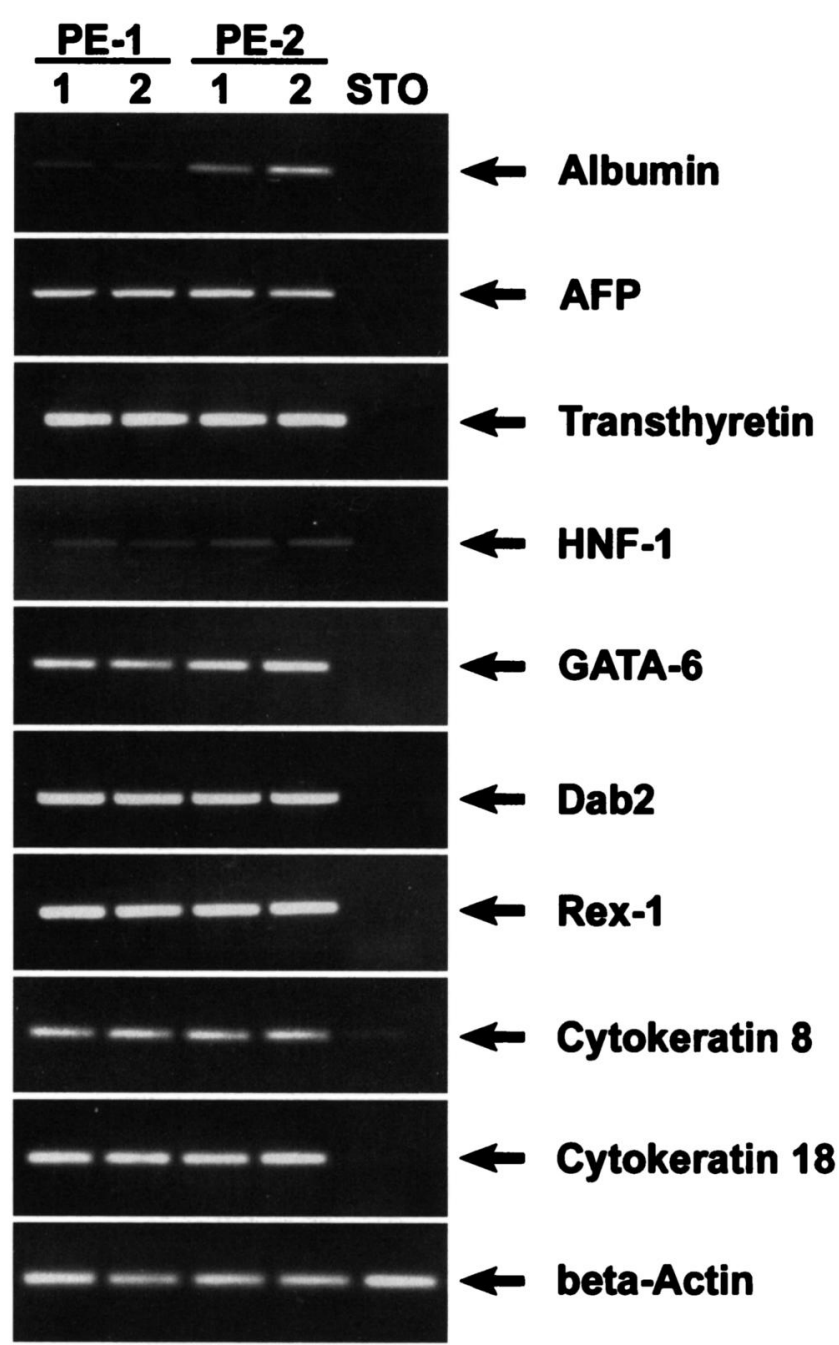

Figure 8. RT-PCR analysis of mRNA expression in PE-1 and PE-2 cells. Two culture flasks ( 1 and 2$)$ were independently assayed for each PE cell line. STO cell mRNA was prepared from cohort feeder cell flasks without any cocultured cells.

(Talbot et al., 2000a). Presumably, desmosome and tight junction connections do not form between the two cell types when their monolayers abut each other in culture. Thus, there was little problem in establishing the endoderm cell lines in pure form.

The in vivo-derived PE-1 and PE-2 cell lines were similar to the CE-2B cell line previously isolated from a bovine blastocyst produced by in vitro fertilization (Talbot et al., 2000a). They were similar in ultrastructural features with the exception that the PE cells examined did not have the numerous and robust Golgi complexes that were a striking feature of the CE-2B cells. In this way, the PE cells appeared more like the in vivo bovine endoderm cells analyzed from a 19-d filamentous bovine blastocyst (Talbot et al., 2005). The PE cells were perhaps most similar to the bovine CE-2B cells in cell and colony morphology, growth rate, and transferrin secretion. Besides transferrin, PE-1 cells produced several other serum proteins as was previously shown to be a characteristic of the CE-2B cell line (Talbot et al., 2000a) and of visceral endoderm cells in general (Janzen et al., 1982; Young and Klein, 1983; Shi et al., 1985).

A possible application of the proteomic profiling of the secreted proteins produced by visceral endoderm cell lines would be in the analysis of "nuclear reprogramming" in embryos produced by somatic cell NT. Nuclear cloned embryos have aberrant gene expression patterns that presumably arise from abnormal genetic imprinting and other epigenetic changes (Humpherys et al., 2002; Cezar et al., 2003; Santos et al., 2003). These failures to reset the genetic structure to that created by the union of egg and sperm (normal fertilization) probably lead to the fetal death so often experienced by NT embryos (Hill et al., 2000; De Sousa et al., 2001; Hashizume et al., 2002). Some of these lethal genetic errors in RNA and protein expression might be detectable in yolk-sac endoderm cell lines (Kharroubi et al., 2001). Comparing serum protein production between in vivo-derived and NT-derived endoderm cell lines might enable the identification of serum protein markers of nuclear reprogramming failures that lead to abnormal growth or embryonic death (Huang et al., 1995; Bavik et al., 1996; Farese et al., 1996). Similarly, NT-related changes in the nonsecretory proteins of the yolk-sac endoderm could be analyzed in endoderm cell lines (Raabe et al., 1998; Strope et al., 2004). It is conceivable that secreted protein markers could be assayed without the destruction of NT pig embryos flushed from the pig uterus at days 11 or 12 of development. This might then allow for the subsequent embryo transfer of selected, and putatively superior, embryos back into the surrogate sows. Likewise, markers of this kind might be applicable to the study of in vitroproduced pig embryo pregnancy failures (Rath et al., 1995; Kikuchi et al., 2002). In any case, the evaluation of several cell lines independently derived from in vivo- and in vitrofertilized embryos will be necessary to establish what differences, found in NT embryo-derived endoderm cell lines, simply reflect variations in endoderm cell population selection, i.e., growth and survival, in response to adapting to the in vitro environment.

The PE cell lines were found to express several transcription factors that have been associated with extraembryonic endoderm differentiation and function, i.e., TCF-1, GATA-6, DAB2, and REX-1 (Morrisey et al., 1998; Barbacci et al., 1999; Morrisey et al., 2000; Fujikura et al., 2002; Thompson and Gudas, 2002). Some of these factors are also involved in embryonic and adult hepatocyte differentiation and function (Xanthopoulos and Mirkovitch, 1993; Hatzis and Talianidis, 2001; Divine et al., 2004; Maurer and Cooper, 2006). It is, therefore, important to be able to distinguish between yolk-sac endoderm and hepatocytes in culture, particularly now when the means to generate hepatocytes from embryonic stem (ES) cells is 

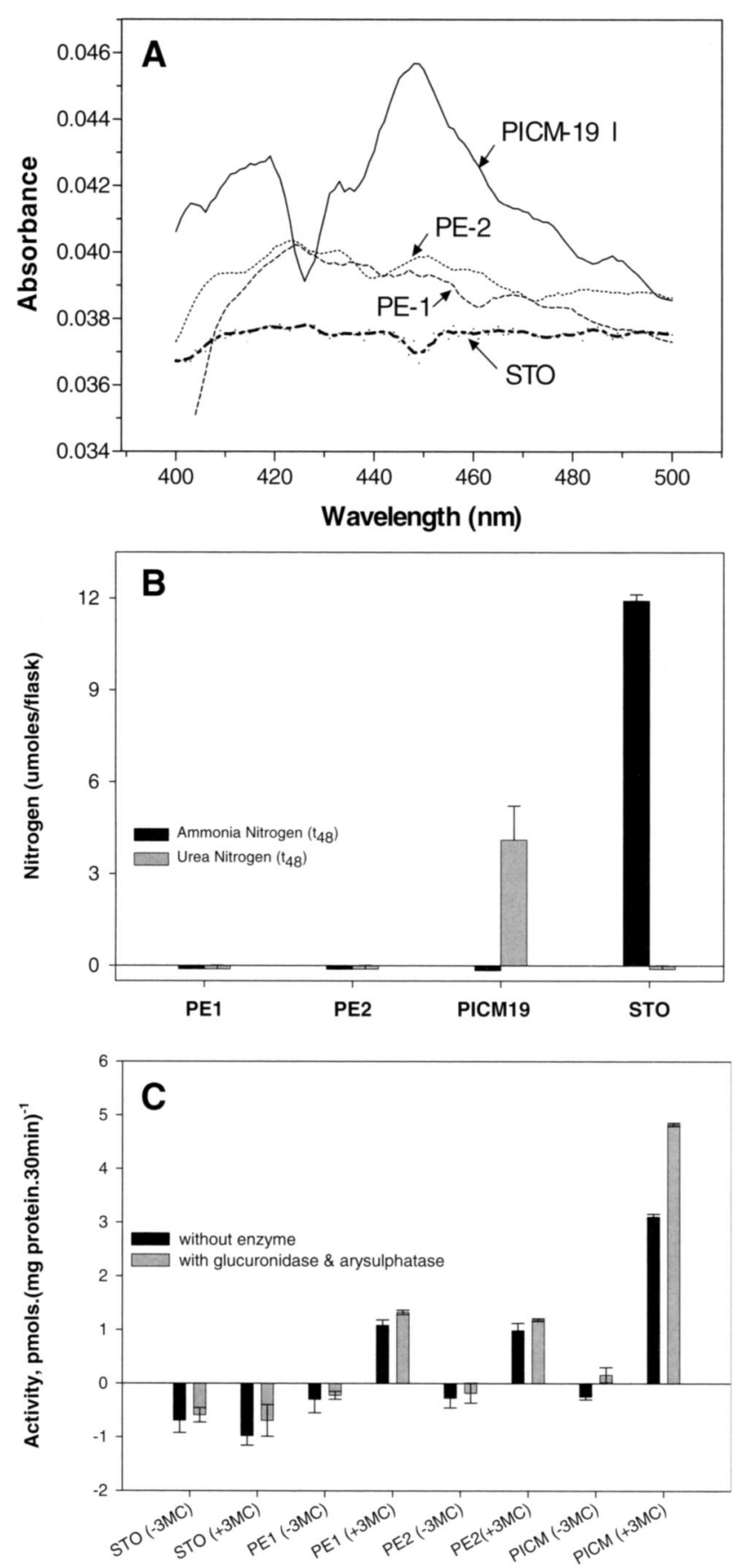

Figure 9. Metabolic activity of PE-1, PE-2, PICM-19, and STO cells. (A) Total P-450 content. $(B)$ Ammonia clearance and urea production. (C) CYP1A1 P-450 activity. Each plot represents two experiments. Two flasks were used per cell type.

being intensively pursued by numerous laboratories. In the past, the differentiation of primate or mouse ES and embryonal carcinoma cells into visceral endoderm has been demonstrated (Adamson and Hogan, 1984; Thomson et al., 1996; Fujikura et al., 2002; Conley et al., 2004). More recently, several laboratories have offered evidence of in vitro methods for the directed differentiation of ES cells into hepatocytes (Hamazaki et al., 2001; Rambhatla et al., 2003;
Chinzei et al., 2002; Schwartz et al., 2005; Novik et al., 2006). Given the many hepatocyte characteristics that are shared by the porcine yolk-sac endoderm cell lines, it is important that claims of hepatocyte differentiation from ES cells be thoroughly proven. While the in vitro morphology of the PE cells is very different from that of primary hepatocytes in culture, those inexperienced in the normal morphology of these two epithelia might not see their distinctive differences. For example, the lack of biliary canalicular structures between PE cells and the frequent formation of domes in PE monolayers do not occur in hepatocyte monolayers. Be that as it may, like cultured hepatocytes, the PE cells produced numerous serum proteins (Figs. 7 and 8). Also, some cytochrome P-450 content and activity were found in the PE cell lines (Fig. 9) although at lower levels than in the positive control PICM19 pig liver cell line and also lower than would be expected in primary adult pig hepatocyte cultures (Talbot et al., 1996). Although aromatase might be expected to be present in the PE cells, the conversion of the P450 EROD substrate, ethoxy resorufin, by aromatase would be unexpected (King and Ackerley, 1985; Conley et al., 1994; Yelich et al., 1997). In any case, modest levels of EROD activity were found in the PE cell lines, and therefore, some specie(s) of cytochrome $\mathrm{P} 450$ with ethoxy resorufin-o-deethylase activity, e.g., P4501A, was inducible in the PE cells as it was in the PICM-19 pig hepatocyte cells (Fig 9B). Another hepatocyte characteristic that PE cell lines displayed was the ability to clear ammonia from the cell culture medium (Fig. 9C). The PE cell lines reduced the ammonia content of the medium to the same extent as the PICM-19 cells, i.e., to beyond the level of detection in the assay. In contrast to the other functional assays, however, the assay of urea production showed a clear difference between the PE cells and the PICM-19 hepatocytes (Fig. 9C). Therefore, while it may be anticipated that other specific differences can be found (Asahina et al., 2004), the production of urea appeared to be definitive for hepatocytes. Thus, reports of ES cell differentiation into hepatocytes should include, as at least some have (Chinzei et al., 2002; Schwartz et al., 2005), the assay of urea production by the cells.

Table 3. Gamma-glutamyltranspeptidase (GGT) levels of PE-1 and PE-2 cells

\begin{tabular}{lcclc}
\hline Cell line & Flask 1 & Flask 2 & Flask 3 & Average \\
\hline PE-1 & $85.5^{\mathrm{a}}$ & 79.9 & - & 82.7 \\
PE-2 & 146.9 & 105.1 & - & 126.0 \\
PICM-19H & 149.8 & 162 & 173.5 & 161.8 \\
STO & BD $^{\mathrm{b}}$ & BD & - & - \\
\hline
\end{tabular}

${ }^{a}$ GGT in milliunits per milligram protein

${ }^{\mathrm{b}} \mathrm{BD}=$ below detection 
A distinct morphological feature previously observed in primary cultures of porcine and bovine visceral endoderm cells was the phase-contrast-dark web-like pattern of unidentified cytoskeletal elements that ran through the cytoplasm and encircled the nucleus of these cells (Talbot et al., 1993, 1995). As previously described for the parthenogenetic bovine visceral endoderm cell line established by our laboratory (Talbot et al., 2005), the immunocytochemical analysis of actin and tubulin defined the similar cytoskeletal elements observed in PE-1 and PE-2 cells as a robust microtubule network. This compares well with the robust microtubule networks found in the in vivo endoderm cells lining the interior of an 11-d porcine embryo (Fig. 4E). This feature may reflect the microtubule networks' major role in the transport of endosomes in endocytotic or transcytotic movement of nutrients through the yolk-sac epithelium (Starling et al., 1983; Beckman et al., 1997).

In summary, this is the first published work demonstrating the establishment of porcine visceral endoderm cell lines. Their yolk-sac endoderm character was exemplified by the in vitro production of a spectrum of serum proteins and by their expression of several transcription factors associated with endoderm differentiation and function. The use of STO coculture for establishing and growing pig yolk-sac endoderm appears to provide a good, functional in vitro model of this vital early embryonic tissue. The initiation and establishment of the endoderm cultures was unproblematic, and, therefore, it is assumed that more PE cells lines could be readily created from various genetic backgrounds and even from pig embryos deriving from NT. Besides the "standard" culture conditions, this in vitro model of porcine endoderm enables the experimental manipulation of the cell line's environment (e.g., addition of specific growth factors, hormones, metabolites, etc.) to question how gene expression responses are changed within a single cell line and in comparison to other endoderm cell lines. It is anticipated that functional comparisons with IVF- or NT-derived visceral endoderm cell cultures will yield information relevant to the in vivo yolk sac's role in supporting the growth and survival of pre- and periimplantation porcine embryos.

Acknowledgments We thank Drs. John McMurtry and John M. Talbot for their helpful editorial and scientific comments on the manuscript. We also thank Mr. Paul Graninger for the technical assistance in tissue culture and proteomic analysis of secreted proteins. A portion of the work was supported by a Cooperative Research and Development Agreement between the Agricultural Research Service and Hepalife Technologies, Inc., 60 State Street, Suite 700, Boston, MA.

Disclaimer Mention of trade names or commercial products in this publication is solely for the purpose of providing specific information and does not imply recommendation or endorsement by the US Department of Agriculture.

\section{References}

Adamson, E.D.; Hogan, B.L. Expression of EGF receptor and transferrin by F9 and PC13 teratocarcinoma cells. Differentiation 27: 152-7; 1984.

Adamson, E.D.; Strickland, S.; Tu, M., et al. A teratocarcinomaderived endoderm stem cell line (1H5) that can differentiate into extra-embryonic endoderm cell types. Differentiation 29: 68-76; 1985.

Anderson, L.L. Growth, protein content and distribution of early pig embryos. Anat. Rec. 190: 143-54; 1978.

Asahina K.; Fujimori H.; Shimizu-Saito K., et al. Expression of the liver-specific gene Cyp7al reveals hepatic differentiation in embryoid bodies derived from mouse embryonic stem cells. Genes Cells 9: 1297-308; 2004.

Barbacci, E.; Reber, M.; Ott, M.O., et al. Variant hepatocyte nuclear factor 1 is required for visceral endoderm specification. Development 126: 4795-805; 1999.

Bavik, C.; Ward, S.J.; Chambon, P. Developmental abnormalities in cultured mouse embryos deprived of retinoic by inhibition of yolk-sac retinol binding protein synthesis. Proc. Natl. Acad. Sci. U. S. A. 93: 3110-4; 1996.

Beckman, D.A.; Lloyd, J.B.; Brent, R.L. Investigations into mechanisms of amino acid supply to the rat embryo using wholeembryo culture. Int. J. Dev. Biol. 41: 315-8; 1997.

Carlson, B.M. Patten's Foundations of Embryology. New York, NY: McGraw-Hill; 1981: 197-200.

Cezar, G.G.; Bartolomei, M.S.; Forsberg, E.J., et al. Genome-wide epigenetic alterations in cloned bovine fetuses. Biol. Reprod. 68: 1009-14; 2003.

Chinzei, R.; Tanaka, Y.; Shimizu-Saito K., et al. Embryoid-body cells derived from a mouse embryonic stem cell line show differentiation into functional hepatocytes. Hepatology 36: 22-9; 2002.

Conley, A.J.; Christenson, L.K.; Ford, S.P.; Christenson, R.K. Immunocytochemical localization of cytochromes P450 17 alphahydroxylase and aromatase in embryonic cell layers of elongating porcine blastocysts. Endocrinology 135: 2248-54; 1994.

Conley, B.J.; Trounson, A.O.; Mollard, R. Human embryonic stem cells form embryoid bodies containing visceral endoderm-like derivatives. Fetal Diagn. Ther. 19: 218-23; 2004.

De Sousa, P.A.; King, T.; Harkness, L., et al. Evaluation of gestional deficiencies in cloned sheep fetuses and placentae. Biol. Reprod. 65: 23-30; 2001.

Divine, J.K.; Staloch, L.J.; Haveri, H., et al. GATA-4, GATA-5, and GATA- 6 activate the rat liver fatty acid binding protein gene in concert with HNF-1alpha. Am. J. Physiol. Gastrointest. Liver Physiol. 287: G1086-9; 2004.

Donato, M.T.; Gomez-Lechon, M.J.; Castell, J.V. A microassay for measuring cytochrome P450IA1 and P450IIB1 activities in intact human and rat hepatocytes cultured on 96-well plates. Anal. Biochem. 213: 29-33; 1993.

Farese, R.V. Jr.; Cases, S.; Ruland, S.L., et al. A novel function for apolipoprotein B: lipoprotein synthesis in the yolk sac is critical for maternal-fetal lipid transport in mice. J. Lipid Res. 37: 347$60 ; 1996$.

Flechon, J.E.; Laurie, S.; Notarianni, E. Isolation and characterization of a feeder-dependent, porcine trophectoderm cell line obtained from a 9-d blastocyst. Placenta 16: 643-58; 1995.

Fujikura, J.; Yamato, E.; Yonemura, S., et al. Differentiation of embryonic stem cells is induced by GATA factors. Genes Dev. 16: 784-9; 2002. 
Hamazaki, T.; Iiboshi, Y.; Oka, M., et al. Hepatic maturation in differentiating embryonic stem cells in vitro. FEBS Lett. 497: $15-9 ; 2001$.

Hashizume, K.; Ishiwata, H.; Kizaki, K., et al. Implantation and placental development in somatic cell clone recipient cows. Cloning Stem Cells 4: 197-209; 2002.

Hatzis, P.; Talianidis, I. Regulatory mechanisms controlling human hepatocyte nuclear factor 4alpha gene expression. Mol. Cell. Biol. 21: 7320-30; 2001.

Hill, J.R.; Burghardt, R.C.; Jones, K., et al. Evidence for placental abnormalities as the major cause of mortality in first-trimester somatic cell cloned bovine fetuses. Biol. Reprod. 63: 1787-94; 2000.

Huang, L.S.; Voyiaziakis, E.; Markenson, D.F., et al. Apo B gene knockout in mice results in embryonic lethality in homozygotes and neural tube defects, male infertility, and reduced HDL cholesterol ester and apo A-I transport rates in heterozygotes. J. Clin. Invest. 96: 2152-61; 1995.

$\rightarrow$ Humpherys, D.; Eggan, K.; Akutsu, H., et al. Abnormal gene expression in cloned mice derived from embryonic stem cell and cumulus cell nuclei. Proc. Natl. Acad. Sci. U. S. A. 99: 12889-94; 2002.

Inoue, K.; Kodha, T.; Lee, J., et al. Faithful expression of imprinted genes in cloned mice. Science 295: 297; 2002.

Janzen, R.G.; Mably, E.R.; Tamaoki, T., et al. Synthesis of alphafetoprotein by the pre-implantation and post-implantation bovine embryo. J. Reprod. Fertil. 65: 105-10; 1982.

Kadokawa, Y.; Kato, Y.; Eguchi, G. Cell lineage analysis of the primitive and visceral endoderm of mouse embryos cultured in vitro. Cell Differ. 21: 69-76; 1987.

Kharroubi, A.B.; Piras, G.; Stewart, C.L. DNA demethylation reactivates a subset of imprinted genes in uniparental mouse embryonic fibroblasts. J. Biol. Chem. 276: 8674-80; 2001.

Kikuchi, K.; Onishi, A.; Kashiwazaki, N., et al. Successful piglet production after transfer of blastocysts produced by a modified in vitro system. Biol. Reprod. 66: 1033-41; 2002.

Laemmli, U.K. Cleavage of structural proteins during the assembly of the head of bacteriophage T4. Nature 277: 680-85; 1970.

King, G.J.; Ackerley, C.A. Demonstration of oestrogens in developing pig trophectoderm and yolk sac endoderm between days 10 and 16. J. Reprod. Fertil. 73: 361-7; 1985.

Liwska, J.; Grabinski-Baranowski, A.J. Ultrastructure of the secondary yolk sac in pig's embryo. Folia Morphol. (Warsz.) 53: 269$83 ; 1994$.

Marrable, A.W. The Embryonic Pig: A Chronological Account. London, England: Sir Isaac Pitman and Sons, LTD; 1971: 7-24 and $76-82$.

Maurer, M.E.; Cooper, J.A. The adaptor protein Dab2 sorts LDL receptors into coated pits independently of AP-2 and ARH. J. Cell Sci. 119(Pt 20): 4235-46; 2006.

Minuth, W.W.; Tiedemann, K. The pig yolk sac II. Analysis of synthesized proteins. Histochemistry 68: 147-58; 1980.

Morrisey, E.E.; Musco, S.; Chen, M.Y., et al. The gene encoding the mitogen-responsive phosphoprotein Dab2 is differentially regulated by GATA- 6 and GATA- 4 in the visceral endoderm. J. Biol. Chem. 275: 19949-54; 2000.

Morrisey, E.E.; Tang, Z.; Sigrist, K.; et al. GATA6 regulates HNF4 and is required for differentiation of visceral endoderm in the mouse embryo. Genes Dev. 12: 3579-90; 1998.

Mossman, H.W. Vertebrate Fetal Membranes. New Brunswick, NJ: Rutgers University Press; 1987: 279-91.

Mummery, C.L.; van Achterberg, T.A.E.; van den Eijnden-van Raaji, A.J.M., et al. Visceral-endoderm-like cell lines induce differentiation of murine P19 embryonal carcinoma cells. Differentiation 46: 51-60; 1991.
Niimi, G.; Usuda, N.; Shinzato, M., et al. A light and electron microscopic study of the mouse visceral yolk sac endodermal cells in the middle and late embryonic periods, showing the possibility of definitive erythropoiesis. Ann. Anat. 184: 425-29; 2002.

Novik, E.I.; Maguire, T.J.; Orlova, K., et al. Embryoid body-mediated differentiation of mouse embryonic stem cells along a hepatocyte lineage: insights from gene expression profiles. Tissue Eng. 12: 1515-25; 2006.

Pera, M.F.; Blasco-Lafita, M.J.; Mills, J. Cultured stem-cells from human testicular teratomas: the nature of human embryonal carcinoma, and its comparison with two types of yolk-sac carcinoma. Int. J. Cancer 40: 334-43; 1987.

$\rightarrow$ Raabe, M.; Flynn, L.M.; Zlot, C.H., et al. Knockout of the abetalipoproteinemia gene in mice: reduced lipoprotein secretion in heterozygotes and embryonic lethality in homozygotes. Proc. Natl. Acad. Sci. U. S. A. 95: 8686-91; 1998.

Rambhatla, L.; Chiu, C.P.; Kundu, P., et al. Generation of hepatocytelike cells from human embryonic stem cells. Cell Transplant 12: 1-11; 2003.

Rath, D.; Niemann, H.; Torres, C.R.L. In vitro development to blastocysts of early porcine embryos produced in vivo or in vitro. Theriogenology 43: 913-26; 1995.

Santos, F.; Zakhartchenko, V.; Stojkovic, M., et al. Epigenetic marking correlates with developmental potential in cloned bovine preimplantation embryos. Current Biol. 13: 1116-21; 2003.

Schwartz, R.E.; Linehan, J.L.; Painschab, M.S., et al. Defined conditions for development of functional hepatic cells from human embryonic stem cells. Stem Cells Dev. 14: 643-55; 2005.

Seaton, B.; Ali, A. Simplified manual high performance clinical chemistry methods for developing countries. Med. Lab. Sci. 41: 327-36; 1984.

Sepulveda, A.R.; Habib, G.M.; Damjanov, A., et al. Expression of gamma-glutamyl transpeptidase in midgestation mouse yolk sac and mouse visceral yolk sac carcinoma cells. Exp. Cell Res. 219: 494-8; 1995.

Shi, W.K.; Hopkins, B.; Thompson, S., et al. Synthesis of apolipoproteins, alphafoetoprotein, albumin, and transferrin by the human foetal yolk sac and other foetal organs. J. Embryol. Exp. Morphol. 85: 191-206; 1985.

Sklan, D.; Ross, A.C. Synthesis of retinol-binding protein and transthyretin in yolk sac and fetus in the rat. J. Nutr. 117: 43642; 1987.

Starling, D.; Duncan, R.; Lloyd, J.B. The role of microtubules in pinocytosis. Inhibition of fluid-phase pinocytosis in rat visceral yolk sac by mitoclasic and related agents. Cell Biol. Int. Rep. 7: 593-602; 1983.

Stroband, H.W.J.; Taverne, N.; Bogaard, M.V.D. The pig blastocyst: its ultrastructure and the uptake of protein macromolecules. Cell Tissue Res. 235: 347-56; 1984.

Strope, S.; Rivi, R.; Metzger, T., et al. Mouse amnionless, which is required for primitive streak assembly, mediates cell-surface localization and endocytic function of cubilin on visceral endoderm and kidney proximal tubules. Development 131: 4787-95; 2004.

Talbot, N.C.; Caperna, T.J.; Edwards, J.L., et al. Bovine blastocystderived trophectoderm and endoderm cell cultures: interferon-tau and transferrin expression as respective in vitro markers. Biol. Reprod. 62: 235-47; 2000a.

Talbot, N.C.; Caperna, T.J.; Lebow, L.T., et al. Ultrastructure, enzymatic, and transport properties of the PICM-19 bipotent liver cell line. Exp. Cell. Res. 225: 22-34; 1996.

Talbot, N.C.; Caperna, T.J.; Powell, A.M., et al. Isolation and characterization of a bovine visceral endoderm cell line derived from a parthenogenetic blastocyst. In Vitro Cell. Dev. Biol. Anim. 41: 130-41; 2005. 
Talbot, N.C.; Garrett, W.M.; Caperna, T.J. Analysis of the expression of aquaporin-1 and -9 in pig liver tissue: comparison with rat liver tissue. Cells, Tissues, Organs 174: 17-28; 2003.

Talbot, N.C.; Powell, A.; Garrett, W., et al. Ultrastructural and karyotypic examination of in vitro produced bovine embryos developed in the sheep uterus. Tissue Cell 32: 9-27; 2000b.

Talbot, N.C.; Powell A.; Rexroad, C.E. Jr. In Vitro pluripotency of epiblasts derived from bovine blastocyst. Mol. Reprod. Dev. 42, 35-52; 1995.

Talbot, N.C.; Rexroad, C.E. Jr.; Pursel, V., et al. A continuous culture of pluripotent fetal hepatocytes derived from the 8-d epiblast of the pig. In Vitro Cell. Dev. Biol. 30A: 843-50; 1994.

Talbot, N.C.; Rexroad, C.E. Jr.; Pursel, V.G., Powell A.M.; Nel, N.D. Culturing the epiblast cells of the pig blastocyst. In Vitro Cell. Dev. Biol., 29A, 543-554; 1993

Thomson, J.A.; Kalishman, J.; Golos, T.G., et al. Pluripotent cell lines derived from common marmoset (Callithrix jacchus) blastocysts. Biol. Reprod. 55: 254-9; 1996.

Thompson J.R.; Gudas L.J. Retinoic acid induces parietal endoderm but not primitive endoderm and visceral endoderm differenti- ation in F9 teratocarcinoma stem cells with a targeted deletion of the Rex-1 (Zfp-42) gene. Mol. Cell. Endocrinol. 195: 11933; 2002.

Tiedemann, K.; Minuth, W.W. The pig yolk sac I. Fine structure of the posthaematopoietic organ. Histochemistry 68: 133-46; 1980.

Walter, G.; Intek, A.; Wobus, A.M., et al. Serological characterization of a pluripotent mouse embryonal stem cell line, two transformed derivatives, and an endoderm-like cell line. Cell Differ. 15: 147$51 ; 1984$.

Wybenga, D.R.; Di Giorgio, J.; Pileggi V.J. Manual and automated methods for urea nitrogen measurement in whole serum. Clin. Chem. 17: 891-95; 1971.

Xanthopoulos, K.G.; Mirkovitch, J. Gene regulation in rodent hepatocytes during development, differentiation and disease. Eur. J. Biochem. 216: 353-60; 1993.

Yelich, J.V.; Pomp, D.; Geisert, R.D. Ontogeny of elongation and gene expression in the early developing porcine conceptus. Biol. Reprod. 57: 1256-65; 1997.

Young, M.F.; Klein, N.W. Synthesis of serum proteins by cultures of chick embryo yolk sac endodermal cells. Dev. Biol. 100: 50-8; 1983. 